\title{
Kwaliteit in borstkankerzorg
}

Citation for published version (APA):

Boersma, L. J. (2015). Kwaliteit in borstkankerzorg: O.K. \& T.O.F. ?! Maastricht University. https://doi.org/10.26481/spe.20151002lb

Document status and date:

Published: 02/10/2015

DOI:

10.26481/spe.20151002lb

Document Version:

Publisher's PDF, also known as Version of record

\section{Please check the document version of this publication:}

- A submitted manuscript is the version of the article upon submission and before peer-review. There can be important differences between the submitted version and the official published version of record.

People interested in the research are advised to contact the author for the final version of the publication, or visit the DOI to the publisher's website.

- The final author version and the galley proof are versions of the publication after peer review.

- The final published version features the final layout of the paper including the volume, issue and page numbers.

Link to publication

\footnotetext{
General rights Owners
rights.

- You may freely distribute the URL identifying the publication in the public portal. please follow below link for the End User Agreement:

www.umlib.nl/taverne-license

Take down policy

If you believe that this document breaches copyright please contact us at:

repository@maastrichtuniversity.nl

providing details and we will investigate your claim.
}

Copyright and moral rights for the publications made accessible in the public portal are retained by the authors and/or other copyright owners and it is a condition of accessing publications that users recognise and abide by the legal requirements associated with these

- Users may download and print one copy of any publication from the public portal for the purpose of private study or research.

- You may not further distribute the material or use it for any profit-making activity or commercial gain

If the publication is distributed under the terms of Article $25 \mathrm{fa}$ of the Dutch Copyright Act, indicated by the "Taverne" license above, 
Kwaliteit in borstkankerzorg:

O.K. \& T.O.F. ?! 


\section{Colofon}

Design \& print: Canon Business Services, Maastricht

ISBN: 978-90-5681-455-7

NUR: 876

Alle rechten voorbehouden. Niets van deze uitgave mag worden verveelvoudigd, opgeslagen in een geautomatiseerd gegevensbestand of openbaar gemaakt worden, zonder voorafgaande schriftelijke toestemming van de auteur of uitgever. 


\section{Kwaliteit in borstkankerzorg: O.K. \& T.O.F. ?!}

Inaugurele rede

Maastricht, 2 oktober 2015

Door Prof.dr. Liesbeth Boersma 
Kwaliteit in borstkankerzorg: O.K. \& T.O.F. ?! 
Mijnheer de Rector, collegae, vrienden en familie,

De titel van mijn oratie heeft al vele nieuwsgierige reacties opgeleverd; sommigen hebben de afkorting O.K. en T.O.F. zelfs al gegoogeld maar men kwam er toch niet helemaal uit. Ik wil u de komende 45 minuten uitleggen wat ik hiermee bedoel en waarom ik voor deze titel gekozen heb. Het belangrijkste doel van mijn leerstoel is het verbeteren van de oncologische zorg in de regio en meer specifiek de borstkankerzorg. Daarbij komt meteen het begrip "kwaliteit van zorg" om de hoek kijken. Ik zal daarom eerst laten zien wat voor mij de vijf belangrijkste aspecten van de kwaliteit van oncologische zorg zijn, en vervolgens wat er zoal gedaan is en gebeurt op die vlakken. Ik zal afsluiten met de plannen die ik binnen mijn leerstoel wil gaan uitvoeren.

Allereerst: wat is kwaliteit van zorg? Het begrip "kwaliteit van zorg" heeft helaas een wat stoffig en bureaucratisch imago voor ons zorgprofessionals: we zien stapels papier voor ons (zelfs in dit digitale tijdperk!) en snappen niet veel van het abstracte vakjargon dat veelal gebruikt wordt. Een andere associatie die velen van ons hebben met het woord kwaliteit is: allerlei ranglijstjes, opgesteld door verzekeraars en kranten.

Die ranglijsten zijn maar lastig: zoals $u$ in figuur 1 ziet, kan het gebeuren dat een ziekenhuis een score 90 krijgt volgens krant 1 en een score 15 volgens krant 2; de scores komen dus niet overeen en zo ziet $u$ een ware sterrenhemel in plaats van een rechte lijn. Het blijkt dus enorm lastig om kwaliteit van zorg goed te definiëren. Zoals echter blijkt uit de ranglijsten, leven we in een tijdperk waar alles gemeten moeten worden. Hoewel ik denk dat lang niet alles zo eenvoudig meetbaar is, helpt het wel, vooral om aanknopingspunten te vinden voor verbetering. Als ik dan op die manier over het begrip "kwaliteit van de oncologische zorg" nadenk, kom ik tot vijf belangrijke aspecten van deze kwaliteit, die meetbaar zijn, of meetbaar te maken zijn. De vijf aspecten die ik zou willen onderscheiden zijn:

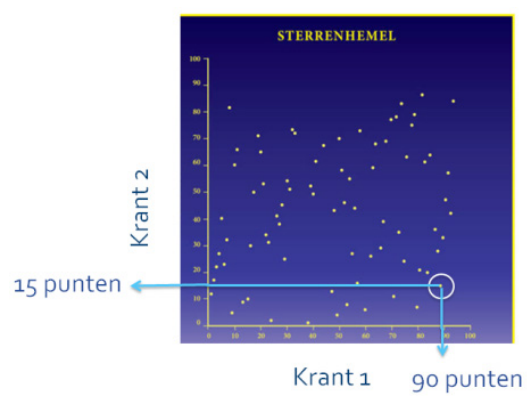

Figuur 1. Door verschillende scores van krant 1 en 2 ontstaat een sterrenhemel. 
1) Allereerst gaat het er natuurlijk om dat we de tumor vernietigen zodat de Overlevingskans zo hoog mogelijk wordt, ...

2) Samen met zo min mogelijk bijwerkingen, dus met een zo goed mogelijke Kwaliteit van leven.

Hiermee is de O.K. in de titel al verklaard.

De drie letters T.O.F. komen voort uit de volgende drie aspecten van kwaliteit van zorg:

3) Tevreden patiënten: voor de patiënt blijft het ontzettend lastig de kwaliteit van de behandeling in termen van "overleving en kwaliteit van leven" te beoordelen; de patiënt ervaart vooral of hij of zij tevreden is of niet. Daarbij is niet alleen een vriendelijke en empatische bejegening van het grootste belang, maar steeds meer patiënten vinden het belangrijk om zelf de regie in handen te kunnen houden. Daarvoor is goede voorlichting essentieel, zodat patiënt en zorgverlener samen tot besluitvorming kunnen komen wat er moet gaan gebeuren. Dit onderwerp, samen beslissen, staat uitgebreid nationaal, en ook internationaal op de agenda, en ook op mijn agenda:

Dit is eigenlijk de kern van mijn visie: we moeten niet alleen op zoek gaan naar behandelingen die weer een extra procentje winst in kans op overleving realiseren, maar we moeten ook proberen de bijwerkingen van de behandeling daarbij te betrekken, en veel belangrijker nog, de patiënt te helpen om samen de juiste afwegingen te maken in zijn of haar individuele situatie.

In mijn beleving kan dit alles echter alleen als we goede randvoorwaarden creëren, en de zorg betaalbaar houden, zoals een goede Organisatie van de zorg - de O in T.O.F.

4) Eén van de belangrijkste aandachtspunten bij de Organisatie van zorg is een goede afstemming tussen de verschillende zorgverleners die bij één patiënt betrokken zijn, zowel op het medisch

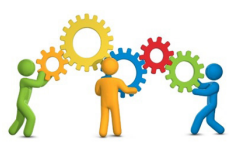
inhoudelijke vlak, als ook op logistiek vlak. Als al deze radartjes soepel 
met elkaar draaien hoeven patiënten niet onnodig lang te wachten op hun diagnose of behandeling. Dit lijkt een open deur maar is in de praktijk nog lang niet altijd een vanzelfsprekendheid.

5) De $\mathbf{F}$ staat voor Foutloos; we moeten de excellente behandeling die we met z'n allen hebben bedacht, dan natuurlijk ook foutloos uitvoeren!

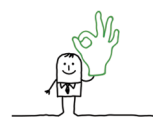

Het belangrijkste mysterie: waar staat O.K. en T.O.F. voor, is nu opgelost. Nu ga ik u, per onderdeel, laten zien wat in de grote lijnen de stand van zaken is op deze facetten en dus waar we onze kracht op moeten inzetten om de oncologische zorg verder te verbeteren.

\section{Ad O: verbeteren van de Overleving}

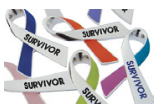

Zoals $u$ in figuur 2 ziet, hebben we echt stappen voorwaarts gemaakt met z'n allen; daar waar in begin 90-er jaren slechts $77 \%$ van de borstkankerpatiënten na vijf jaar nog in leven was, is dat ondertussen al $87 \%$ geworden.

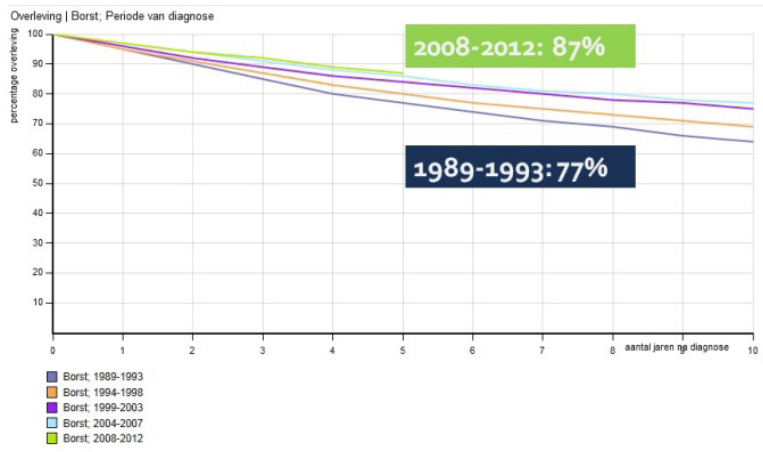

Figuur 2. De overleving na de diagnose borstkanker is sterk verbeterd in de loop der jaren. Bron: www.ciffersoverkanker.nl

Dat heeft verschillende oorzaken. Alle aspecten vanaf diagnose tot en met behandeling zijn de afgelopen jaren substantieel verbeterd [Elkin \& Hudis, 2015]: we hebben het bevolkingsonderzoek, waardoor we de borstkanker eerder ontdekken; we hebben betere methodes om de tumoruitbreiding goed in kaart te brengen zoals de MRI, maar ook de contrast-enhanced mammografie, die hier in het MUMC+ als enige in 
Nederland geïmplementeerd is door Marc Lobbes [Lobbes et al, 2014]. Doordat we de tumor beter in beeld kunnen brengen, kunnen we betere keuzes maken in de behandeling. We kunnen bij de behandeling van borstkanker drie types behandelingen onderscheiden:

1) Operatie: verwijderen van de tumor uit de borst, en van eventueel aangedane regionale lymfeklieren.

2) Bestraling: bestraling van de borst en eventueel aangedane regionale lymfeklieren.

Dit zijn samen de zogenaamde locoregionale behandelingen.

3) Medicamenteuze therapie, d.w.z. behandeling met medicijnen die in het hele lichaam komen, zodat eventuele uitzaaiingen ook aangepakt kunnen worden. Dit is veelal chemotherapie, maar kan ook bestaan uit hormoontherapie, of immunotherapie, zoals Trastuzumab.

Op al deze vlakken is veel vooruitgang geboekt. De belangrijkste bijdrage in betere overleving is te danken aan betere medicijnen, zoals Trastuzumab. Daarnaast heeft bestraling ook een bijdrage geleverd aan de verbeterde overleving [Clarke et al, 2014].

De bestraling is de laatste 10-20 jaar ook technisch gezien enorm verbeterd. In figuur 3 ziet $u$ bijvoorbeeld hoe we een bestralingsplan maken: we maken eerst een $\mathrm{CT}$ scan: een dwarsdoorsnede van het lichaam met behulp van röntgenstralen vastgelegd. De rode contour is ingetekend rondom het borstklierweefsel,

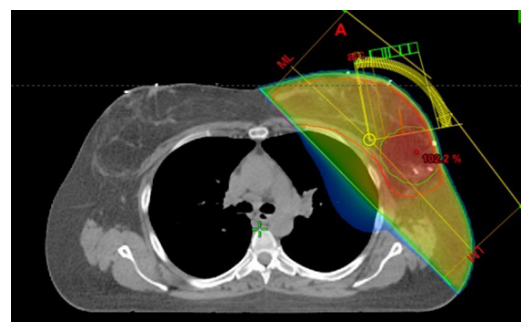

Figuur 3. CT- coupe: een dwarsdoorsnede door het menselijk lichaam, met de dosis hierop in kleur weergegeven.

de groene contour om het gebied met veranderingen in het weefsel als gevolg van de operatie, dus het gebied waar de tumor gezeten heeft. Daaroverheen geprojecteerd is de geplande bestralingsdosis weergegeven: in rood de hoge dosis op de plek van de tumor, in geel de lagere dosis in de rest van de borst, en in blauw de echt lage dosis, die je eigenlijk helemaal niet zou willen hebben. Met de software kan worden opgegeven van welke kanten er bestraald wordt en dan kan de dosis berekend worden voor ieder punt op deze scan. Zo kunnen we heel goed uitrekenen welke dosis waar komt en kunnen we er voor zorgen dat de borst goed bestraald wordt, maar omliggende weefsels zoals hart en 
longen, zo veel mogelijk gespaard worden. Hoewel we grofweg eigenlijk altijd zeggen dat bestraling een lokale behandeling is, die geen effect buiten het bestraalde gebied heeft, zijn er recent wel zeer spannende ontwikkelingen, die suggereren dat bestraling een soort immuunreactie teweeg brengt, waardoor bestraling op bijvoorbeeld een uitzaaiing in de oksel, ook een eventuele microscopische uitzaaiing elders zou kunnen bestrijden. De laboratoriumresultaten uit MAASTRO [Zegers et al, 2015] en recent ook de eerste klinische resultaten gepubliceerd door een groep uit New York [Golden et al, 2015] zijn hoopgevend, maar moeten hun waarde in de praktijk nog verder bewijzen. Binnenkort zal een fase 1 studie starten in MAASTRO CLINIC om dit immuun-effect verder te onderzoeken bij patiënten, onder leiding van Evert van Limbergen en Philippe Lambin.

Om wat achtergronden te schetsen van de ontwikkeling van de gedachtes over hoe de ziekte borstkanker zich gedraagt, wil ik u meenemen naar begin 1900. In die tijd dacht de chirurg Halsted (18521922) dat borstkanker een ziekte was die begon in de borst, na verloop van tijd uitzaaiingen gaf naar de lymfeklieren, en dan nog een stap later, uitzaaiingen via het bloed naar andere organen, zoals longen, lever, botten en hersenen. Op het moment dat je er dan dus vroeg bij was, en de borst en lymfeklieren radicaal verwijderde, zou je dan genezen moeten zijn! Volgens dokter Fisher (1918-) klopte die theorie helemaal niet, want heel regelmatig kregen patiënten die zo radicaal geopereerd waren, toch nog uitzaaiingen in de organen. Fisher stelde daarom dat borstkanker altijd vanaf het begin af aan al in het hele lichaam zit en dat je daarom eigenlijk altijd met medicijnen zoals chemotherapie zou moeten behandelen. Een operatie en bestraling waren volgens hem alleen zinvol om te voorkomen dat er bijvoorbeeld grote wonden in de borst of lymfeklieren ontstonden. Zoals vaak met dit soort uitersten denken wij nu dat de waarheid in het midden ligt: borstkanker is een heterogene ziekte, een ziekte die begint in de borst en die zich, afhankelijk van de specifieke kenmerken van de tumor, al dan niet verspreidt via lymfebanen en of bloed [Fisher \& Anderson, 2010]. Daar waar we dus tot halverwege de jaren 90 dachten dat radiotherapie vooral zinvol was om hernieuwde tumorgroei in de borst te voorkomen, met alle gevolgen van dien, bleek halverwege de jaren 90 dat bestraling ook de overlevingskans verbeterde. Dit was een vrij revolutionaire bevinding! 
Ook bleek dat een radicale operatie, zoals een borstamputatie, vaak helemaal niet nodig was: de opkomst van de borstsparende behandeling in de jaren 90. Grote studies, zowel in de Verenigde Staten als in Europa, lieten zien dat een borstsparende operatie gevolgd door bestraling van de borst een even veilige behandeling was als een borstamputatie. Met even veilig werd bedoeld: met een zelfde overleving; echter de tumor kwam vooral bij de jongere patiëntengroepen toch nog vaker terug in de borst. Daarom hebben we tussen 2004 en 2011 de Young Boost Trial (YBT) [trial nummer op www.clinicaltrials.gov: NCT00212121] uitgevoerd bij patiënten van 50 jaar of jonger. Ongeveer 1200 patiënten kregen de standaard dosis op de borst, met een lage extra dosis op de plek waar de tumor had gezeten en ongeveer 1200 patiënten kregen een hoge extra dosis op de plek waar de tumor had gezeten. Omdat we weten dat de tumor ook na vijf jaar nog kan terugkomen, is het nog te vroeg om nu al te zeggen of de hogere bestralingsdosis ook geleid heeft tot het minder vaak terugkomen van de tumor, maar die gegevens wachten we natuurlijk met spanning af. Wel kunnen we laten zien dat voor de hele groep patiënten in de YBT, de kans dat de tumor terugkomt extreem klein is geworden, waarschijnlijk als gevolg van alle zojuist geschetste verbeteringen in de behandeling. In de 80-er jaren was de kans dat de tumor in de borst terugkomt binnen 10 jaar na de behandeling nog rond de $20 \%$, in de 90 -er jaren rond de $10 \%$, en in de YBT was dit volgens de laatste analyse rond de $2 \%$ na 8 jaar [Poortmans et al, 2012]!

Nu het zo goed gaat met het onder controle krijgen van de tumor, wordt het dus steeds belangrijker om de bijwerkingen van de behandeling goed af te wegen tegen de voordelen. En zo komen we bij de het volgende aspect van kwaliteit: Kwaliteit van leven.

\section{Ad K: Kwaliteit van leven}

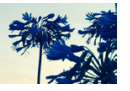

Als de tumor eenmaal onder controle is, dan wordt de kwaliteit van leven vooral bepaald door de bijwerkingen van de behandeling. Belangrijke bijwerkingen van de "locoregionale" behandeling van borstkanker, dat wil dus zeggen de operatie gevolgd door bestraling, bestaan uit:

1) Een beperkte schouderfunctie en/of het ontstaan van lymfeoedeem van de arm, indien de oksellymfeklieren behandeld zijn. Recente studies laten zien dat een okselklier operatie veilig vervangen kan worden door bestraling, met als gevolg minder kans op een dikke arm [Donker et al, 2014]. Misschien kan okselbehandeling zelfs 
helemaal achterwege gelaten worden, maar hierover is nog veel discussie. Daarom zijn er recent twee landelijke studies gestart vanuit Maastricht, onder leiding van Marjolein Smidt, om dit nader te onderzoeken.

2) Door bestraling wordt het bestraalde weefsel vaak stugger en harder, als gevolg van littekenvorming. Dit kan tot gevolg hebben dat de cosmetische uitkomst verslechtert: daar waar de patiënt vaak direct na de operatie zo blij was met het cosmetisch resultaat, kan dat in de loop van de maanden tot jaren na de behandeling toch gaan tegenvallen. De mate van verlittekening is van vele factoren afhankelijk en uit eerdere studies is al een aantal factoren bekend [Immink et al, 2012], maar ook wij doen hier nog verder onderzoek naar; daar kom ik later nog op terug.

3) Een andere bijwerking van de bestraling van de linker borst kan bijvoorbeeld schade aan het hart zijn. Dit kan leiden tot een hartinfarct 10-30 jaar na de behandeling [Hooning et al, 2007]. Omdat het pas zo lang na de behandeling ontstaat, is dit lang niet onderkend. Sinds we dit weten, zijn er technieken ontwikkeld om het hart steeds beter te ontzien: bestraling tijdens diepe inademing.

Met Bart Reymen en Jacques Borger waren we in 2005 bij de eersten in Nederland die deze techniek hebben geïmplementeerd bij patiënten met linkszijdige borstkanker. In figuur 4 ziet $u$ in rood de hartcontour tijdens diepe inademing, in geel tijdens vrije ademhaling. $U$ kunt zien dat het hart veel slanker wordt, en zich van de borst af beweegt tijdens de diepe inademing. Hoewel deze techniek dus al een enorme sprong vooruit is geweest in het voorkomen van hartschade, werkt het helaas niet bij iedereen. Vooral indien de klieren achter het borstbeen bestraald moeten worden, is het lastiger het hart voldoende te ontzien.
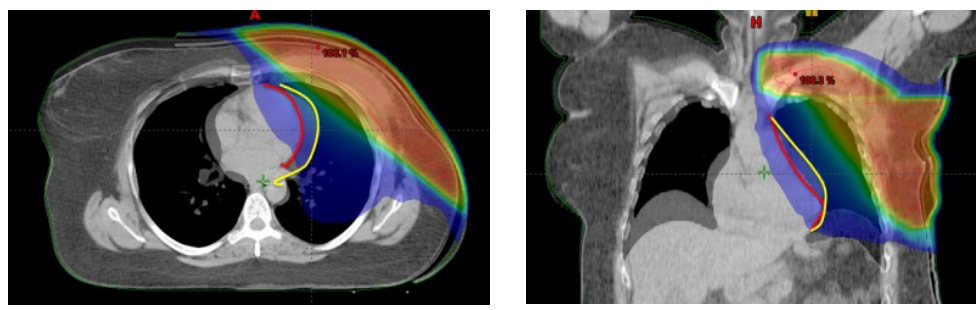

Figuur 4. Het hart beweegt van het hoge dosis gebied af door diepe inademing, zoals zichtbaar op de dwarsdoorsnede (links) en bij vooraanzicht (rechts). 
Protonen zouden verder kunnen bijdragen tot verminderen van hartschade. Zoals $u$ wellicht heeft gelezen in de media, hebben we hiervoor in Maastricht een vergunning gekregen, net als drie anderen in Nederland. Op het moment zijn we heel hard bezig om de financiering rond te krijgen en we streven er naar de eerste patiënt in 2018 te behandelen met protonen. Wat is protonentherapie nu eigenlijk? Protonentherapie is een vorm van bestralen, waarbij het nog beter lukt om de gezonde weefsels te sparen. Bij borstkanker zit de verwachte winst vooral in het verlagen van de hartdosis. Een andere winst die we denken te bereiken is dat door de lagere dosis in de gezonde weefsels, er nog minder kans is op het ontwikkelen van kanker als gevolg van bestraling. Vooral bij jonge vrouwen, tot ongeveer 40 jaar, is het risico verhoogd om, zo'n 15 tot 20 jaar na de bestraling, een tweede tumor te ontwikkelen [Grantzau \& Overgaard, 2015], dus als we dat kunnen voorkomen, is dat zeer relevant.

De maatschappelijke discussie die zich over protonen voordoet, is of die protonen niet veel te duur zijn en of het sparen van de gezonde weefsels wel altijd klinisch relevant is: leidt die lagere hartdosis ook daadwerkelijk tot minder hartinfarcten of minder tweede tumoren? De uitdaging ligt er dus voor ons om de protonen zo selectief toe te passen, dat ze kosteneffectief zijn, dus dat ze alleen worden toegepast in situaties waar we het risico op klachten met gewone bestraling echt significant kunnen verminderen. Daarvoor is in Nederland een prachtige methode bedacht, die ook in het buitenland met zeer veel interesse wordt gevolgd [Langendijk et al, 2013]. Heel in het kort wordt bij deze methode gebruik gemaakt van voorspellingsmodellen: met behulp van deze modellen wordt de kans op bijwerkingen berekend voor een protonen bestralingsplan en voor een "gewoon" fotonen bestralingsplan. Op grond van het berekende verschil wordt besloten om wel of niet over te gaan op een protonenbestraling.

Voor het maken van deze voorspellingsmodellen zijn heel veel gegevens nodig, de zogenaamde "big data", of zoals wij het liever noemen: "Rapid Learning Technieken" [Lambin et al, 2013]. MAASTRO CLINIC vervult hierin een voortrekkersrol via André Dekker en Philippe Lambin, die data over de hele wereld combineren tot voorspellingsmodellen, zoals te zien op de website www.predictcancer.org. Bij een dergelijk model kan de arts kenmerken van de individuele patiënt invullen, bijvoorbeeld of het een man of vrouw betreft, of hij of zij in goede conditie is, hoe groot de tumor is, en of er lymfeklieren aangedaan zijn. Het model rekent dan voor die individuele patiënt uit in welke risicogroep de patiënt valt, en wat dan de kans op 
overleven na 2 jaar is. Afgezien van deze kenmerken verwachten we ook dat als we hier in de toekomst nog de genetische profielen aan toevoegen, de voorspelling steeds nauwkeuriger, en dus steeds meer op de individuele patiënt gericht kan worden.Ook zullen we de behandeling dan in het model opnemen, zodat we weten welke behandeling tot welke uitkomsten leidt bij die individuele patiënt. Als je eenmaal een betrouwbaar model hebt om de kans op overleving èn de kans op bijwerkingen te voorspellen bij een bepaalde behandeling, kan dat de patiënt enorm helpen om samen met de arts die behandeling te kiezen die het beste bij hem of haar past, zodat we tevreden patiënten krijgen: de $\mathbf{T}$ van T.O.F.

\section{Ad T: Tevreden patiënten}

Tevredenheid van patiënten hangt ongetwijfeld samen met het verstrekken van de juiste informatie en de mogelijkheid van de

patiënt om mee te beslissen bij de behandelkeuze. Dit is echter makkelijker gezegd dan gedaan. Hoewel samen beslissen eigenlijk als een open deur klinkt -natuurlijk moet de patiënt mee beslissen- is het een vak apart, en de maatschappij is er nog niet helemaal klaar voor. Daar waar we vroeger iedere patiënt individueel behandelden, kwam er in de jaren daarna steeds meer roep om uniformiteit en protocollen: het zou toch niet zo mogen zijn dat de patiënt bij dokter A een andere behandeling krijgt dan bij dokter B? Dit heeft er toe geleid dat er allerlei richtlijnen zijn ontwikkeld, gebaseerd op eerdere studies. Het vreemde met richtlijnen is echter, dat ze enorm paternalistisch zijn.

Ik herinner me de eyeopener, toen ik net in mijn eerste jaar van de opleiding tot radiotherapeut een borstkankerwerkgroep in Amsterdam bezocht, waar uitgebreid gediscussieerd werd hoeveel winst de chemotherapie moest geven om het op te nemen in de richtlijn. We vroegen ons af of een verbetering van $80 \%$ naar $83 \%$ voldoende was om chemotherapie te adviseren, of pas als het van $80 \%$ naar $85 \%$ verbetert? Mijn mond viel open: moesten wij beslissen welke afweging de patiënt zou maken? Nog steeds is het zo dat in de landelijke richtlijn er vanuit wordt gegaan dat chemotherapie "de moeite waard is" als de overlevingskans met 5\% toeneemt (en dus 95\% van de mensen het voor niets krijgt!); bestraling wordt in het algemeen in de richtlijn opgenomen als de kans dat de tumor terugkomt in het oorspronkelijke gebied ergens tussen de $10-20 \%$ is zonder bestraling (en dus bij 80-90\% niet!). Ik denk echter dat slechts weinig artsen de discussie met de patiënt aangaan van "u kunt ook kiezen voor geen behandeling", als het volgens de 
richtlijn wel aanbevolen wordt. Dit wordt nog eens extra lastig, omdat allerlei kwaliteitslijstjes controleren of we de richtlijnen volgen en als we dat in minder dan $80 \%$ van de patiënten doen, worden er vraagtekens gezet bij de geleverde kwaliteit. Desalniettemin moet ons dit natuurlijk niet tegenhouden de voor-en nadelen met de patiënt te bespreken!

Om dit te vergemakkelijken wordt er de laatste tijd met hernieuwde energie ingezet op keuzehulpen. Hiervan is aangetoond dat deze een positief effect hebben op de kennis van patiënten, en op hun keuzespijt [Stacey et al, 2014]. In MAASTRO CLINIC proberen we onze voorspellingsmodellen te verwerken in de keuzehulpen: we vragen de patiënt / of we helpen de patiënt om een paar gegevens die we nodig hebben om de uitkomst in te schatten, in te voeren in de keuzehulp, zodat de patiënt alleen informatie krijgt die specifiek op haar van toepassing is, en niet op de hele groep borstkankerpatiënten. We proberen die getallen ook visueel te maken, zodat patiënten zich er meer bij voor kunnen stellen, zoals in dit plaatje (Figuur 5).

Dergelijke plaatjes hebben we bijvoorbeeld gebruikt in de keuzehulp, die we met het hele mammateam in het MUMC+ gemaakt hebben

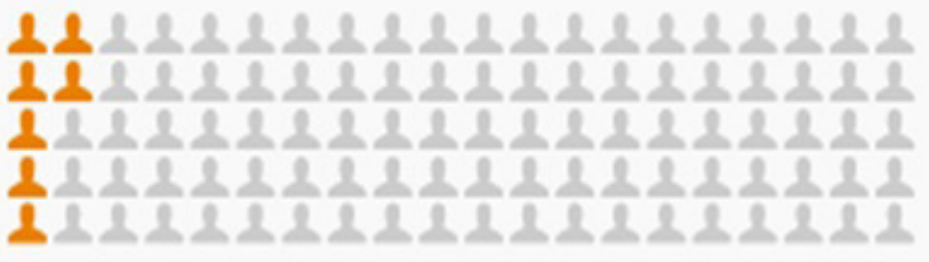

Figuur 5. Een visuele manier om het begrip $7 \%$, ofwel 7 van de 100 patiënten uit te drukken.

in samenwerking met Zorgkeuzelab, om de keuze te ondersteunen tussen een borstsparende behandeling of een borstamputatie. Wilma Savelberg, een van mijn Ph.D.-studenten, heeft een pilot test gedaan in een drietal ziekenhuizen met een Pink Ribbon subsidie en zal deze keuzehulp nog verder gaan evalueren met een Alpe D'HuZes subsidie [Savelberg et al, 2015].

Tevreden patiënten, hoe goed doen we het eigenlijk in de radiotherapie en kunnen we dat meten? Er is vorig jaar een pilot onderzoek gedaan met een vragenlijst die de tevredenheid van patiënten meet. De radiotherapie in Nederland scoorde een 9.1 op een schaal van 10. Dat is natuurlijk 
al enorm hoog, maar een belangrijk punt waarop nog ruimte voor verbetering was, is het aspect informatie over behandelopties. Dat sluit goed aan bij ons voornemen om samen beslissen verder uit te bouwen en te implementeren. De keuzehulpen die we daarvoor aan het ontwikkelen zijn, of al gemaakt zijn, helpen ons ook om als multidisciplinair team, dus als chirurgen, medisch oncologen, en radiotherapeuten samen, nog beter dezelfde ideeën uit te stralen en dezelfde neutrale informatie aan de patiënt te geven. Om dit goed te implementeren is een nog betere regionale samenwerking ook essentieel en zo kom ik bij de Organisatie.

\section{Ad O: Organisatie van zorg}

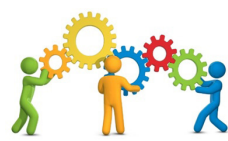

Bij kanker is er over het algemeen sprake van meerdere specialisten die zich met één patiënt bezig houden. Alle behandelingen moeten natuurlijk goed op elkaar afgestemd zijn, door goede zorgpaden te definiëren, zowel inhoudelijk als logistiek. Als voorbeeld van onze regionale multidisciplinaire samenwerking kan ik u de MaZorg studie laten zien die we van 2004 tot 2009 in onze regio hebben uitgevoerd, om de nazorg voor borstkankerpatiënten te verbeteren. Door heel goed samen te werken met de mammapoli's van alle ziekenhuizen, konden we deze studie doen en aantonen dat af en toe een goed telefonisch gesprek door de mammacare verpleegkundige in combinatie met een informatieve groepsbijeenkomst, kosten-effectiever is dan de patiënt standaard iedere drie maanden bij de specialist te laten komen. Het zou zelfs tot vijf miljoen Euro per jaar aan besparing leiden als we dit landelijk zouden invoeren. Dat hebben we echter niet gedaan, omdat we ook de nazorg beter wilden laten aansluiten op de individuele voorkeuren van de patiënt. Daarvoor hebben we een vervolg onderzoek gestart, waar ik later nog op terugkom. De studie heeft wel al geleid tot een aanpassing van de landelijke richtlijnen en tot het prachtige proefschrift van Merel Kimman, mijn eerste Ph.D.-student [Kimman, 2010]. We moeten echter natuurlijk niet alleen voor de nazorg goed samenwerken in de regio, maar ook met betrekking tot de behandeling.

De bestraling wordt in Limburg slechts op twee locaties uitgevoerd: in Maastricht en in Venlo. Om toch goed samen te kunnen werken, komen wij als radiotherapeuten in alle ziekenhuizen in de regio. We hebben in ieder ziekenhuis één of meer spreekuren en geven advies in de patiëntenbesprekingen over de kankerpatiënten in die ziekenhuizen. Om een verdere verbeterslag in de samenwerking te maken, is ook het 
OncoZON netwerk opgericht: Oncologisch netwerk Zuidoost-Nederland. De bedoeling van dit netwerk is om, door alle disciplines uit alle ziekenhuizen goed met elkaar samen te werken, de kwaliteit van de oncologische zorg in de regio verder te verbeteren. Ik kom hier later nog op terug.

Ook binnen MAASTRO CLINIC werken we veel aan onze interne organisatie: we hebben een zogenaamd datawarehouse, waarin we met dashboards bijvoorbeeld onze doorstroomtijden inzichtelijk maken. De groene verticale balken in figuur 6 moeten eigenlijk minstens tot $80 \%$ reiken, dus tot de rode lijn.

U ziet dat we in 2011 redelijk goede doorlooptijden hadden, maar we zagen dat dit in 2012 - 2013 enorm verslechterde. Dat kwam doordat we toen in 1,5 jaar tijd al onze bestralings-toestellen

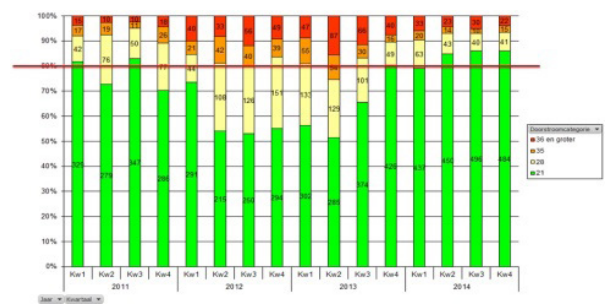

Figuur 6. Voorbeeld van Dashboard om doorstroomtijden inzichtelijk te maken. hebben vervangen, wat ten koste ging van onze aandacht en menskracht voor de logistiek. We hebben daarna twee jaar vol ingezet op de zogenaamde FLOW-projecten, om te zorgen dat de patiënt als het ware soepel door onze organisatie stroomde. Dat dat resultaat heeft gehad ziet $u$ in figuur 6 : de doorlooptijden van 2014 voldoen weer aan de norm en dat is nu in 2015 nog steeds zo. Deze gegevens helpen ons uitstekend om inzichtelijk te maken waar onze aandacht het hardste nodig is en het stimuleert natuurlijk ook enorm als je ziet dat de inspanningen resultaat hebben.

In deze FLOW-projecten hebben we, onder leiding van onze lean-expert Huub Backes, alle stappen die een patiënt bij ons doorloopt onder de loep genomen. Bij iedere stap vroegen we ons af: is deze stap wel echt nodig? Heeft de patiënt er echt wat aan dat we dat doen? Doen we die stap allemaal op dezelfde manier, bedoelen we allemaal hetzelfde met deze instructie? Deze manier van analyseren leidt niet alleen tot snellere processen, maar ook tot betere kwaliteit en veiligheid en minder fouten. Zo kom ik automatisch uit op mijn vijfde aspect, de derde letter van T.O.F: de F van Foutloos. 


\section{Ad F: Foutloos}

藩

In MAASTRO CLINIC hebben we veel aandacht voor veiligheid met Petra Reijnders als voortrekker. We hebben een cultuur weten te creëren met een hoge meldingsbereidheid: er worden veel meldingen gemaakt van zaken die niet gaan volgens de afspraken, en we maken iedere keer weer verbeterslagen aan de hand van deze meldingen. Hierdoor is het aantal meldingen in de loop der jaren gestaag afgenomen. De critici onder u zullen zeggen: dat komt misschien wel door een verminderde meldingsbereidheid? Om dat te onderzoeken hebben we in MAASTRO CLINIC onderzoek gedaan met behulp van interviews en vragenlijsten onder de medewerkers. Hieruit bleek dat in 2013 veel minder medewerkers vonden dat onze patiëntveiligheid slechts acceptabel was dan in 2010 en dat in 2013 veel meer medewerkers dan in 2010 vonden dat we een zeer goede patiëntveiligheid hadden. Dat wij dat niet alleen zelf vinden blijkt ook uit het feit dat MAASTRO CLINIC één van de eerste radiotherapie afdelingen was die het veiligheidscertificaat van Lloyd ontving figuur 7A). Recent zijn we opnieuw gevisiteerd, nu door weer een andere onafhankelijke visiteur (DEKRA), die aangaf onder de indruk te zijn van ons veiligheidsklimaat (figuur 7B).
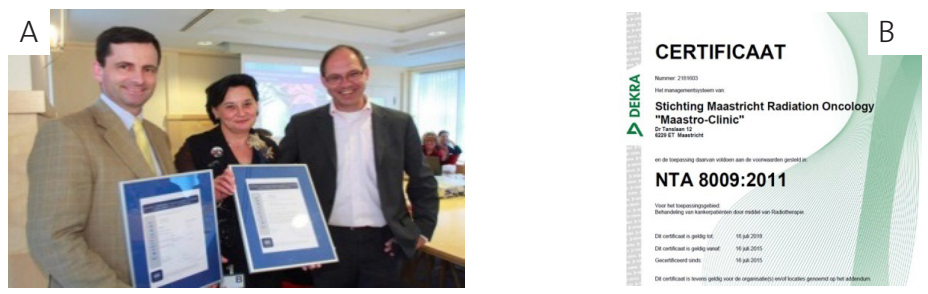

Figuur 7. Uitreiking van eerste veiligheidscertificaat van Lloyd (A), en recent van DEKRA (B).

Ik heb $u$ laten zien wat er zoal gebeurt of gebeurd is op de O.K. en T.O.F.aspecten van kwaliteit van borstkankerzorg; in het laatste deel van mijn oratie wil ik u laten zien op welke aspecten ik zal inzoomen binnen mijn leerstoel. 


\section{Plannen}

Zoals eerder gezegd, vind ik het enorm belangrijk om een goede afweging te maken tussen de kans op overleving en een goede kwaliteit van leven, en vooral om die aan te laten sluiten bij de psyche, wensen, en voorkeuren van de individuele patiënt. Dit gaat dus over de eerste drie domeinen van kwaliteit van zorg die ik met $u$ besprak: overleving, kwaliteit van leven, en de tevreden patiënt. Binnen mijn leerstoel zal ik dan ook met name focusseren op het beter selecteren van de juiste behandeling, passend bij de individuele patiënt. Daarvoor zal ik me allereerst richten op het ontwikkelen en/of valideren van modellen waarmee de kans op overleven en bijwerkingen ingeschat kan worden voor een bepaalde behandeling. Voor het maken van deze modellen zijn veel gegevens nodig. Van een aantal studies liggen de gegevens nu klaar voor analyse, andere studies zijn we nog aan het opstarten.

Zo heb ik, samen met andere onderzoekers in het land, in 2010 een subsidie gekregen van het KWF, om de gegevens te verzamelen van alle borstkankerpatiënten in Nederland die als eerste behandeling chemotherapie kregen in plaats van chirurgie en die pas na de chemotherapie geopereerd werden. Omdat dat een relatief nieuwe benadering was in 2010, was het bij deze patiëntengroep vaak niet helemaal duidelijk of deze patiënten dan ook nog bestraald moesten worden. Om hier meer grip op te krijgen zijn van 2011 tot en met 2014 alle patiënten die eerst met chemotherapie behandeld zijn, geregistreerd in de RAPCHEM-studie (Radiotherapy After Primary CHEMotherapy) [NCT01279304]. Deze patiënten zullen nu eerst tenminste vijf jaar vervolgd moeten worden, voordat we iets kunnen zeggen over het effect van aanvullende bestraling. Vorige week nog heb ik een nieuwe subsidie aangevraagd bij het KWF, samen met andere onderzoekers in het land, om een vervolg registratie-studie op te zetten, de zgn. NAPCHEM studie (Nodal staging and treatment After Primary CHEMotherapy), om te onderzoeken of een minder agressieve behandeling van de oksellymfeklieren na chemotherapie veilig is en patiënten de nare bijwerkingen hiervan, zoals een dikke arm en een verminderde schouderfunctie, bespaard kunnen blijven.

Patricia Brouwers, een van mijn Ph.D.-studenten, is bezig om met de gegevens van de Young Boost trial een model te maken om de kans op bijwerkingen, zoals bijvoorbeeld een slechte cosmetische uitkomst, 
te voorspellen. Ook zal ze de gegevens verwerken van onze PLEM: Poli Kliniek Late Effecten Mammacarcinoom, welke ik in 2012 heb geïnitieerd.

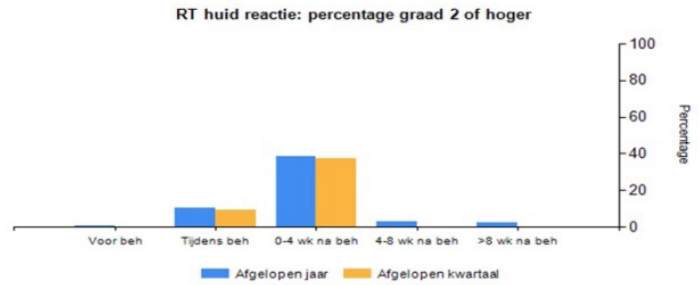

Figuur 8. Voorbeeld van dashboard voor monitoren van acute bijwerkingen van de bestraling.

Daarnaast heb ik, samen met André Dekker, MAASTRO-CLINIC breed een uitkomstenregistratie-project gestart. Onder leiding van Mia Brouns en Iverna Nijsten wordt een systeem opgezet om overleving en bijwerkingen in kaart te brengen van al onze patiënten. In figuur 8 ziet $\mathrm{u}$ al een voorbeeld van de registratie van onze acute bijwerkingen: op ons dashboard worden de bijwerkingen van het afgelopen jaar in blauw en het afgelopen kwartaal in oranje weergegeven, zodat het snel opvalt als er iets verandert. In de komende jaren zullen we meer van deze uitkomsten op deze manier in beeld brengen en zullen we ze ook gaan gebruiken om onze voorspellende modellen verder te ontwikkelen.

Om deze voorspellende modellen ook daadwerkelijk te kunnen gebruiken in het gesprek met de patiënt, heb ik recent, samen met Trudy van der Weijden van de Universiteit van Maastricht (UM), en Nicola Russell uit het Antoni van Leeuwenhoek Ziekenhuis, een Alpe d'HuZes subsidie gekregen om keuzehulpen te ontwikkelen en/of evalueren op een drietal lastige keuzes bij de borstkankerbehandeling. Deze drie keuzes zijn: 1) borstsparende behandeling versus borstamputatie, waarvan de keuzehulp al af is, zoals eerder al genoemd; 2) de keuze wel of geen radiotherapie bij patiënten met een relatief klein risico op tumor terugkeer; en 3) de keuze voor de optimale nazorg strategie,
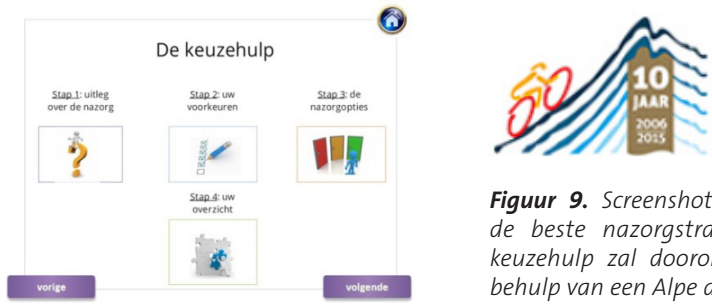

Figuur 9. Screenshot uit de keuzehulp om de beste nazorgstrategie te kiezen. Deze keuzehulp zal doorontwikkeld worden met behulp van een Alpe d'HuZes subsidie. 
als vervolg op de eerder genoemde MaZorg studie. Deze keuzehulp is ontwikkeld door Linda Klaassen, een van mijn Ph.D. studenten, onder mede supervisie van Ciska Hoving van de UM en Carmen Dirksen van het MUMC+, gefinancierd door CZ en VGZ. Deze keuzehulp (figuur 9) wordt momenteel in een pilot op de mammapoli's in de ziekenhuizen in de regio Zuid-Limburg getest.

Tot slot, zoals gezegd, een goede kwaliteit van zorg wordt ook gekarakteriseerd door een goede organisatie: een belangrijk doel van mijn leerstoel is dan ook om ook mijn steentje bij te dragen aan het OncoZON netwerk. Ik ben er van overtuigd dat we met dit netwerk er in zullen slagen een kwaliteitsslag te maken in de oncologische zorg in Zuidoost-Nederland. We zullen hierin bijvoorbeeld gaan organiseren dat er geen algemene besprekingen over kankerpatiënten meer zijn, waar alle tumorsoorten door elkaar besproken worden, maar alleen nog tumor-specifieke, waarbij alle relevante medisch specialisten met expertise op dat aandachtsgebied aanwezig zijn. Zo kunnen alle nuances van de richtlijn goed overwogen worden bij iedere individuele patiënt. We zullen ook moeten nadenken over hoe we het advies van de patiëntenbespreking formuleren, zodat het ook voldoende ruimte biedt om patiëntenvoorkeuren mee te nemen in de besluitvorming.

Het samen doen van onderzoek, innoveren, verzorgen van onderwijs aan nieuwe aanstormende talenten is mijns inziens een absolute voorwaarde om de oncologische zorg in onze regio verder vooruit te helpen. Tevens kan dat ook een belangrijke bindende factor kan; er ligt namelijk ook de uitdaging om zoveel onderling vertrouwen te kweken, dat we elkaar inzage durven te geven in al die aspecten van kwaliteit die ik vandaag genoemd heb: overleving, kwaliteit van leven (dus ook bijwerkingen en complicaties), tevredenheid van patiënten, doorlooptijden en fouten of missers. Dit zodat we van elkaar kunnen leren. Als we bijvoorbeeld zien dat in het ene ziekenhuis patiënten meer tevreden zijn dan in een ander ziekenhuis: waar ligt dat aan, kan het andere ziekenhuis dat ook voor elkaar krijgen? Dit betekent wel dat we binnen het netwerk al deze aspecten ook uniform zullen moeten meten, anders kunnen we natuurlijk niet goed vergelijken. 


\section{Dankwoord}

Dames en heren, ik hoop $u$ meer inzicht te hebben gegeven in mijn plannen om de oncologische zorg - en meer specifiek de borstkankerzorg - te verbeteren. Ik zie dat sommigen van u wat beginnen te knikkenbollen, het wordt tijd voor wat luchtigers en dus voor het dankwoord. Ik ga me enorm beperken, anders zitten we hier vanavond nog, maar $u$ allen hier aanwezig, heeft ieder op zijn/haar eigen manier, een bijdrage aan vandaag geleverd, waarvoor ik u erg dankbaar ben. Om dan toch een paar namen te noemen: Allereerst natuurlijk het College van Bestuur van de Universiteit Maastricht, het Bestuur van de Faculty of Health Medicine en Life Sciences, de Raad van Bestuur van het MUMC+, en mijn Commissie van Toezicht, Albert Scherpbier, Philippe Lambin, Frans Ramaekers en Maria Jacobs: $\mathrm{u}$ allen dank ik voor het in mij gestelde vertrouwen.

Het bereiken van een dergelijke mijlpaal is ook een uitgelezen momentom eens terug te kijken. Mijn beroepsmatige loopbaan is in 1990 begonnen in het AvL in Amsterdam. Ik begon mijn promotieonderzoek onder de bezielende leiding van Joos Lebesque die mij de liefde en kunde voor het vak en voor onderzoek heeft bijgebracht. Na dit promotieonderzoek was ik compleet verkocht. Daar waar ik eerst dacht kinderarts te worden, was het me op dat moment volkomen duidelijk: er was maar één vak: radiotherapie. De opleiding volgde ik ook in Amsterdam, onder leiding van Harry Bartelink. Ik kan zonder meer zeggen dat jij, Harry de belangrijkste mentor bent geweest in mijn ontwikkeling als borstkankerradiotherapeut. Je hebt me voor 1,5 jaar naar Philadelphia laten gaan tijdens de opleiding en naar FLIMS laten gaan om de Young Boost studie te schrijven. Je hebt me altijd gestimuleerd onderzoek te blijven doen, maar vooral eerst een goede patiëntendokter te zijn. Hoewel ik het AvL verlaten heb, terwijl jij eigenlijk hele andere plannen met en voor mij had, werken we gelukkig nog steeds bijzonder prettig samen. Heel veel dank voor alles, ik hoop dat we nog lang zo door mogen gaan!

Op het borstkankergebied ook veel dank aan Philip Poortmans: bijvoorbeeld door mij op te nemen in de teaching staff van de ESTRO borstkankercursus heb je vele deuren voor me geopend; zoals de Skagenmeeting die nu weer gepland staat in juni 2016. Daar komen een aantal Europese borstkankerradiotherapeuten bij elkaar om te brainstormen over welke studies er nodig zijn om de borstkankerradiotherapie weer een stap verder te brengen. 


\section{DE WERELD}

\section{IS MOOIER}

\section{MET}

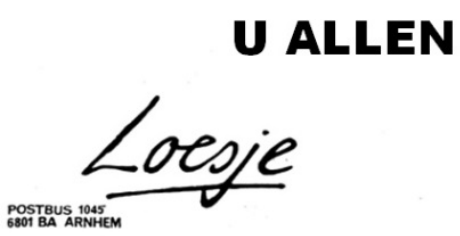

In 2003 ben ik naar MAASTRO CLINIC gekomen; hier kwam ik in een prachtig radiotherapieteam terecht, dat regio-breed de radiotherapie verzorgt. Hier ervaar ik iedere dag weer dat het overgrote deel van ons MAASTRO-team ontzettend enthousiast en gedreven is om het vak vooruit te brengen, daar kan ik echt een warm gevoel van krijgen. Ook in de regio ervaar ik de samenwerking met de borstkankerteams, in het bijzonder met de mammacare- verpleegkundigen, als een feest: hoe wij met zijn allen die MaZorg studie hebben gedaan, en nu weer bezig zijn met de keuzehulp studie, volgens mij kunnen veel regio's daar een voorbeeld aan nemen! Ook in de IKNL tumorwerkgroep is een open en ontspannen sfeer en wil men graag van elkaar leren. Ik heb er echt vertrouwen in dat we dit moeten kunnen voortzetten en uitbouwen in de OncoZON werkgroepen.

Toen ik in 2003 naar het zuiden kwam, was Philippe Lambin medisch directeur in MAASTRO CLINIC. Philippe heeft MAASTRO CLINIC in 10-15 jaar tijd prachtig op de kaart gezet, resulterend in een excellente beoordeling van de KNAW in 2014. Philippe, je hebt mij altijd enorm vrij gelaten en tegelijk ook gesteund. Ik heb me steeds verder kunnen ontwikkelen, niet alleen op borstkanker-onderzoeksgebied, maar ook in het management, wat nu heeft geresulteerd in deze positie; heel veel dank voor je vertrouwen in mij!

Maria Jacobs kwam in 2008 in onze organisatie. Vanaf ongeveer 2009 ging ik me ook meer met management bezig houden en kwam daardoor steeds meer met jou in contact. Op management gebied kan 
ik wel zeggen dat jij mijn grote mentor bent; ik heb al enorm veel van je geleerd en hoop daar nog lang mee door te kunnen gaan. Je hebt me ook in contact gebracht met Mirjam Sibbel, aan wie ik enorm veel dank verschuldigd ben voor de wijze lessen over welke krachten er allemaal spelen in zo'n managementfunctie en vooral ook over mijzelf. Maria, jij bent het ook die zag dat het voor de uitstraling van MAASTRO CLINIC en voor de oncologische zorg in de regio goed zou zijn als er ook vanuit de radiotherapie weer een hoogleraar zou zijn in de directe patiëntenzorg èn die deze mogelijkheden dan ook bij mij zag: zonder jou zou ik hier nu niet gestaan hebben en dat geeft een bijzonder en dankbaar gevoel.

Tot slot: iedereen eindigt altijd met het thuisfront. Eigenlijk is het raar om daar mee te eindigen, want dat is het allerbelangrijkste in mijn leven. Mijn ouders, en ook mijn schoonvader, kunnen dit helaas niet meer meemaken, maar mijn oudste zus schreef meteen toen ze van mijn benoeming hoorde: wat zouden ze trots zijn geweest......Natuurlijk hebben zij, en het hele warme ondersteunende nest waar ik uit kom, de basis gelegd voor dit alles.

Sinds 18 jaar deel ik nu mijn leven met Leo: Lief, ik mocht je niet noemen in mijn dankwoord, maar dat zou nu pas echt gek zijn. Het zat je altijd dwars dat wij elkaar nog niet kenden toen ik promoveerde, dus dat je die ceremonie was misgelopen, maar nu is het dan toch gelukt:vandaag maken we samen deze mooie universitaire ceremonie mee! Zoals we al vaak tegen elkaar gezegd hebben: dit was alleen mogelijk door ons "teamwerk". De tocht hierheen, en eigenlijk ons hele leven, zie ik als een prachtige fietstocht: veel genieten, af en toe afzien, maar of jij nu kopwerk doet of ik, of dat we samen schuilen in het peloton, we laten de ander niet lossen!

Ik heb gezegd. 


\section{Referenties}

1. EBCTCG (Early Breast Cancer Trialists' Collaborative Group), McGale P, Taylor C, Correa C, Cutter D, Duane F, Ewertz M, Gray R, Mannu G, Peto R, Whelan T, Wang Y, Wang Z, Darby S. Effect of radiotherapy after mastectomy and axillary surgery on 10-year recurrence and 20-year breast cancer mortality: meta-analysis of individual patient data for 8135 women in 22 randomised trials. Lancet;383(9935):2127-35, 2014.

2. Elkin EB, Hudis CA Parsing Progress in Breast Cancer. J Clin Oncol 33(26):2837-2839, 2015.

3. Donker M, van Tienhoven G, Straver ME, Meijnen P, van de Velde CJ, Mansel RE, Cataliotti L, Westenberg AH, Klinkenbijl JH, Orzalesi L, Bouma WH, van der Mijle HC, Nieuwenhuijzen GA, Veltkamp SC, Slaets L, Duez NJ, de Graaf PW, van Dalen T, Marinelli A, Rijna H, Snoj M, Bundred NJ, Merkus JW, Belkacemi Y, Petignat P, Schinagl DA, Coens C, Messina CG, Bogaerts J, Rutgers EJ. Radiotherapy or surgery of the axilla after a positive sentinel node in breast cancer (EORTC 1098122023 AMAROS): a randomised, multicentre, open-label, phase 3 noninferiority trial. Lancet Oncol 15(12):1303-10, 2014.

4. Fisher B, Anderson SJ. The Breast Cancer Alternative Hypothesis: Is There Evidence to Justify Replacing It? J Clin Oncol 28(3):366-7, 2010.

5. Golden EB, Chhabra A, Chachoua A, Adams S, Donach M, Fenton-Kerimian M, Friedman K, Ponzo F, Babb JS, Goldberg J, Demaria S, Formenti SC. Local radiotherapy and granulocyte-macrophage colony-stimulating factor to generate abscopal responses in patients with metastatic solid tumours: a proof-of-principle trial. Lancet Oncol 16(7):795-803, 2015

6. Immink JM, Putter H, Bartelink H, Cardoso JS, Cardoso MJ, van der Hulst-Vijgen MH, Noordijk EM, Poortmans PM, Rodenhuis CC, Struikmans $\mathrm{H}$. Long-term cosmetic changes after breast-conserving treatment of patients with stage I-II breast cancer and included in the EORTC 'boost versus no boost' trial. Ann Oncol 23(10):2591-8, 2012.

7. Grantzau T, Overgaard J. Risk of second non-breast cancer after radiotherapy for breast cancer: a systematic review and meta-analysis of 762,468 patients. Radiother Oncol 114(1):56-65, 2015.

8. Hooning MJ, Botma A, Aleman BM, Baaijens MH, Bartelink H, Klijn JG, Taylor CW, van Leeuwen FE Long-Term Risk of Cardiovascular Disease in 10-Year Survivors of Breast Cancer J Natl Cancer Inst. 99(5):365-75, 2007.

9. Kimman M. Improving the Quality and Cost-effectiveness of Breast Cancer Follow-up. Thesis, Univserity Maastricht, November 5th, 2010. 
10. Lambin P, Roelofs E, Reymen B, Velazquez ER, Buijsen J, Zegers CM, Carvalho S, Leijenaar RT, Nalbantov G, Oberije C, Scott Marshall M, Hoebers F, Troost EG, van Stiphout RG, van Elmpt W, van der Weijden T, Boersma L, Valentini V, Dekker A. 'Rapid Learning health care in oncology' - an approach towards decision support systems enabling customised radiotherapy'. Radiother Oncol 109(1):159-64, 2013.

11. Langendijk JA, Lambin P, De Ruysscher D, Widder J, Bos M, Verheij $M$. Selection of patients for radiotherapy with protons aiming at reduction of side effects: the model-based approach. Radiother Oncol 107(3):267-73, 2013.

12. Lobbes MB, Lalji U, Houwers J, Nijssen EC, Nelemans PJ, van Roozendaal L, Smidt ML, Heuts E, Wildberger JE. Contrast-enhanced spectral mammography in patients referred from the breast cancer screening programme. Eur Radiol 24(7):1668-76, 2014.

13. Park JH, Anderson WF, Gail MH. Improvements in US Breast Cancer Survival and Proportion Explained by Tumor Size and EstrogenReceptor Status. J Clin Oncol 33(26):2870-6, 2015

14. Poortmans P, Aznar M, Bartelink $H$. Quality indicators for breast cancer: revisiting historical evidence in the context of technology changes. Semin Radiat Oncol :29-39, 2012.

15. Savelberg W, Moser A, Smidt M, Boersma L, Haekens C, van der Weijden T. Protocol for a pre-implementation and post-implementation study on shared decision-making in the surgical treatment of women with early-stage breast cancer. BMJ Open 5(3):e007698, 2015.

16. Stacey D, Légaré F, Col NF, Bennett CL, Barry MJ, Eden KB, HolmesRovner M, Llewellyn-Thomas H, Lyddiatt A, Thomson R, Trevena L, Wu $\mathrm{JH}$. Decision aids for people facing health treatment or screening decisions. Cochrane Database Syst Rev 1:CD001431, 2014.

17. Zegers CM, Rekers NH, Quaden DH, Lieuwes NG, Yaromina A, Germeraad WT, Wieten L, Biessen EA, Boon L, Neri D, Troost EG, Dubois LJ, Lambin P. Radiotherapy combined with the immunocytokine L19-IL2 provides long-lasting antitumor effects. Clin Cancer Res 21(5):1151-60, 2015. 


